\section{Clinical course of COVID-19 in a series of patients with chronic arthritis treated with immunosuppressive targeted therapies}

Different viral agents are associated with an increased risk of more severe disease course and respiratory complications in immunocompromised patients. ${ }^{1-3}$ The recent outbreak of severe acute respiratory syndrome coronavirus 2 (SARS-CoV-2) disease 2019 (COVID-19) responsible for a severe acute respiratory syndrome (SARS) represents a source of concern for the management of patients with inflammatory rheumatic diseases. Lombardy is the region in Northern Italy with the highest incidence of COVID-19 cases, with more than 33000 confirmed patients and 1250 requiring admission to the intensive care unit within 1 month. Since the first reports of COVID-19 cases in Italy, we have circulated a survey with a 2 -week follow-up contact to patients with chronic arthritis treated with biological disease-modifying antirheumatic drugs (bDMARDs) or targeted synthetic disease-modifying antirheumatic drugs (tsDMARDs) followed up at our biological outpatient clinic in Pavia, Lombardy. The survey investigated the patients' health conditions, the presence of contacts with subjects known to be affected by COVID-19 and management of the DMARDs during the first few weeks of pandemic. All patients had provided their informed consent for the use of personal and clinical data for scientific purposes, and no patient refused to participate.

During the first month, we have collected information on 320 patients (female $68 \%$, mean age $55 \pm 14$ years) treated with bDMARDs or tsDMARDs (57\% with rheumatoid arthritis, $43 \%$ with spondyloarthritis, $52 \%$ treated with tumour necrosis factor inhibitors, $40 \%$ with other bDMARDs and $8 \%$ with tsDMARDs). As shown in table 1, four were confirmed cases of COVID-19 identified through rhinopharyngeal swabs. Another four patients reported symptoms which were highly suggestive of COVID-19. Five additional patients with reported certain contacts remained asymptomatic at the end of the 2-week observation period.

All patients with confirmed COVID-19 received at least one antibiotic course, and the hospitalised patient also received antiviral therapy and hydroxychloroquine. Overall, five patients
Table 1 Clinical characteristics of the patients with confirmed or suspected COVID-19

\begin{tabular}{|c|c|c|c|}
\hline & $\begin{array}{l}\text { Confirmed } \\
\text { COVID-19 }\end{array}$ & $\begin{array}{l}\text { Clinical picture } \\
\text { highly suggestive } \\
\text { of COVID-19 }\end{array}$ & $\begin{array}{l}\text { Contact with } \\
\text { a known } \\
\text { COVID-19 } \\
\text { patient }\end{array}$ \\
\hline Number of patients & 4 & 4 & 5 \\
\hline Age (years) (mean $\pm S D)$ & $58 \pm 5$ & $56 \pm 8$ & $54 \pm 12$ \\
\hline Female, $\mathrm{n}(\%)$ & $4(100)$ & $3(75)$ & $4(80)$ \\
\hline \multicolumn{4}{|l|}{ Comorbidities, n (\%) } \\
\hline Hypertension & $1(25)$ & $2(50)$ & $1(20)$ \\
\hline Diabetes & 0 & 0 & 0 \\
\hline Cardiovascular disease & 0 & 0 & $1(20)$ \\
\hline Other & $4(100)$ & $4(100)$ & $3(60)$ \\
\hline \multicolumn{4}{|l|}{ Smoking, n (\%) } \\
\hline Active & $1(25)$ & 0 & 0 \\
\hline Previous & $2(50)$ & $3(75)$ & $1(20)$ \\
\hline \multicolumn{4}{|l|}{ Rheumatological diagnosis } \\
\hline $\mathrm{RA}, \mathrm{n}(\%)$ & $3(75)$ & $3(75)$ & $5(100)$ \\
\hline $\mathrm{SpA} / \mathrm{PA},{ }^{*} \mathrm{n}(\%)$ & $1(25)$ & $1^{*}(25)$ & 0 \\
\hline \multicolumn{4}{|l|}{ Rheumatological treatment, $\mathrm{n}(\%)$} \\
\hline \multicolumn{4}{|l|}{ bDMARD } \\
\hline Adalimumab & 0 & 0 & $1(20)$ \\
\hline Etanercept & $2(50)$ & $2(50)$ & 0 \\
\hline Abatacept & $1(25)$ & $1(25)$ & 0 \\
\hline Tocilizumab & 0 & 0 & $1(20)$ \\
\hline \multicolumn{4}{|l|}{ tsDMARD } \\
\hline Tofacitinib & $1(25)$ & 0 & $1(20)$ \\
\hline Baricitinib & 0 & $1(25)$ & $2(40)$ \\
\hline \multicolumn{4}{|l|}{ Concomitant csDMARD } \\
\hline Methotrexate & $2(50)$ & $1(25)$ & $3(60)$ \\
\hline Leflunomide & $1(25)$ & 0 & $1(20)$ \\
\hline Sulfasalazine & 0 & $1(25)$ & 0 \\
\hline Concomitant hydroxychloroquine & $1(25)$ & $2(50)$ & $2(40)$ \\
\hline Low-dose glucocorticoids* & $2(50)$ & $2(50)$ & $2(40)$ \\
\hline Known contact with COVID-19 & 0 & $1(25)$ & $5(100)$ \\
\hline \multicolumn{4}{|l|}{ Symptoms, n (\%) } \\
\hline Fever & $4(100)$ & $1(25)$ & 0 \\
\hline Non-productive cough & $3(75)$ & $2(50)$ & 0 \\
\hline Sputum production & $1(25)$ & 0 & 0 \\
\hline Rhinorrhea & $2(50)$ & $1(25)$ & 0 \\
\hline Sore throat & 0 & 0 & 0 \\
\hline Fatigue & $4(100)$ & $2(50)$ & 0 \\
\hline Myalgia & $2(50)$ & $1(25)$ & 0 \\
\hline Arthralgia & $1(25)$ & $1(25)$ & 0 \\
\hline Anosmia/dysgeusia & $3(75)$ & $3(75)$ & 0 \\
\hline Dyspnoea at rest & $1(25)$ & 0 & 0 \\
\hline Dyspnoea on exertion & $2(50)$ & $1(25)$ & 0 \\
\hline Headache & $2(50)$ & 0 & 0 \\
\hline Diarrhoea & $1(25)$ & 0 & 0 \\
\hline Nausea/vomiting & 0 & 0 & 0 \\
\hline Chest X-ray performed & $4(100)$ & $0 \dagger$ & 0 \\
\hline Chest X-ray pathological findings & 0 & 0 & 0 \\
\hline Hospital admission & $1(25)$ & 0 & 0 \\
\hline
\end{tabular}

* Glucocorticoids $\leq 5 \mathrm{mg} /$ day prednisone equivalent.

tSubject to home quarantine.

bDMARD, biological disease-modifying antirheumatic drug; COVID-19, coronavirus disease 2019; csDMARD, conventional synthetic disease-modifying antirheumatic drug; PA, psoriatic arthritis; RA, rheumatoid arthritis; SpA, spondyloarthritis; tsDMARD, targeted synthetic disease-modifying antirheumatic drug.

were on previous stable treatment with hydroxychloroquine. All patients with symptoms of infection temporarily withdrew the bDMARD or tsDMARD at the time of symptom onset. To date, 
there have been no significant relapses of the rheumatic disease. None of the patients with a confirmed diagnosis of COVID-19 or with a highly suggestive clinical picture developed severe respiratory complications or died. Only one patient, aged 65, required admission to hospital and low-flow oxygen supplementation for a few days.

Our findings do not allow any conclusions on the incidence rate of SARS-CoV-2 infection in patients with rheumatic diseases, nor on the overall outcome of immunocompromised patients affected by COVID-19. A high level of vigilance and strict follow-up should be maintained on these patients, including the exclusion of superimposed infections. However, our preliminary experience shows that patients with chronic arthritis treated with bDMARDs or tsDMARDs do not seem to be at increased risk of respiratory or life-threatening complications from SARS-CoV-2 compared with the general population.

These findings are not surprising as the severe respiratory complications caused by coronaviruses are thought to be driven by the aberrant inflammatory and cytokine response perpetuated by the host immune system. ${ }^{4}$ During different coronavirus outbreaks, such as SARS and Middle East respiratory syndrome, there has been no increased mortality reported in patients undergoing immunosuppression for organ transplantation, cancer or autoimmune diseases. ${ }^{35}$ Accordingly, among 700 patients admitted for severe COVID-19 at our hospital (a referral centre for SARS-CoV-2 infection) during last month, none was receiving bDMARDs or tsDMARDs.

Although continuous surveillance of patients with rheumatic diseases receiving immunosuppressive drugs is warranted, these data can support rheumatologists for the management and counselling of their patients, avoiding the unjustifiable preventive withdrawal of DMARDs, which could lead to an increased risk of relapses and morbidity from the chronic rheumatological condition.

Sara Monti $\odot,{ }^{1}$ Silvia Balduzzi, ${ }^{2}$ Paolo Delvino, ${ }^{3}$ Elisa Bellis, ${ }^{3}$ Verdiana Serena Quadrelli, ${ }^{3}$ Carlomaurizio Montecucco ${ }^{3}$

${ }^{1}$ Rheumatology Department, IRCCS Fondazione Policlinico San Matteo, Pavia, Italy ${ }^{2}$ Rheumatology Department, IRCCS Policlinico San Matteo, Pavia, Italy

${ }^{3}$ Rheumatology Department, Fondazione IRCCS Policlinico San Matteo, Pavia, Italy

Correspondence to Dr Sara Monti, Rheumatology, IRCCS Fondazione Policlinico S Matteo, Pavia 27100, Italy; sara.saramonti@gmail.com

\section{Handling editor Josef S Smolen}

Contributors SM and CM contributed to the design of the project interpretation and analysis of the data, and writing of the manuscript. SB, PD, EB and VSQ contributed to the collection of data, interpretation and analysis of the data, and review of the manuscript.

Funding The authors have not declared a specific grant for this research from any funding agency in the public, commercial or not-for-profit sectors.

Competing interests None declared.

Patient and public involvement Patients and/or the public were not involved in the design, or conduct, or reporting, or dissemination plans of this research.

Patient consent for publication Not required.

Provenance and peer review Not commissioned; internally peer reviewed.

\section{(2) OPEN ACCESS}

Open access This is an open access article distributed in accordance with the Creative Commons Attribution Non Commercial (CC BY-NC 4.0) license, which permits others to distribute, remix, adapt, build upon this work non-commercially, and license their derivative works on different terms, provided the original work is properly cited, appropriate credit is given, any changes made indicated, and the use is non-commercial. See: http://creativecommons.org/licenses/by-nc/4.0/.

(C) Author(s) (or their employer(s)) 2020. Re-use permitted under CC BY-NC. No commercial re-use. See rights and permissions. Published by BMJ.

\section{A) Check for updates}

To cite Monti S, Balduzzi S, Delvino P, et al. Ann Rheum Dis 2020;79:667-668.

Received 26 March 2020

Accepted 27 March 2020

Published Online First 2 April 2020

Ann Rheum Dis 2020;79:667-668. doi:10.1136/annrheumdis-2020-217424

ORCID iD

Sara Monti http://orcid.org/0000-0002-1800-6772

\section{REFERENCES}

1 Memoli MJ, Athota R, Reed S, et al. The natural history of influenza infection in the severely immunocompromised vs nonimmunocompromised hosts. Clin Infect Dis 2014;58:214-24.

2 Noreña I, Fernández-Ruiz M, Aguado JM. Viral infections in the biologic therapy era. Expert Rev Anti Infect Ther 2018;16:781-91.

3 D'Antiga L. Coronaviruses and immunosuppressed patients. The facts during the third epidemic. Liver Transp/ 2020. doi:10.1002/lt.25756

4 Shi Y, Wang Y, Shao C, et al. COVID-19 infection: the perspectives on immune responses. Cell Death Differ 2020;382.

5 Hui DS, Azhar El, Kim Y-J, et al. Middle East respiratory syndrome coronavirus: risk factors and determinants of primary, household, and nosocomial transmission. Lancet Infect Dis 2018; 18:e217-27. 